\title{
Digital Revolution: Europe at the Lead of New Technologies
}

\author{
Rada Cristina Irimie \\ Babeş-Bolyai University, Cluj-Napoca, Romania \\ radairimie@yahoo.com
}

Abstract

The pace and scope of changing technologies are constantly challenging social structures and the need for dexterous policy framework is becoming more and more indispensable. While technological evolution and market forces have driven the information and communication revolution, the European Union has played a significant role in creating an effective framework for the maintenance and development of this progress. In order to regulate the market and keep pace with the ICT (Information and Communications Technology) environment, the EU has introduced rules that ensure fair access to all EU citizens and stimulate competition for companies. The Body of European Regulators for Electronic Communications (BEREC) serves entirely this function, becoming a pan-European regulatory agency. Aside the regulatory role, EU's economic growth strategy involves a great number of policies and measures to capitalize on digital revolution. The Digital Agenda for Europe (DAE) targets not only on citizens, but businesses of Europe as well, to benefit from the technological revolution. The former and the new goals of the renewed agenda raise the bar of smart, sustainable and inclusive growth. Finally, to ensure the maximization of use of information technologies, EU has supported the expansion of e-business and online public services. E-government services have facilitated interaction between government, citizens and businesses, while it simplified all facets of operations of governmental organisations. This article is looking at EU's role in digital environments, examining the three initiatives as platforms of technological evolution in Europe. The three case studies used, the BEREC, DAE and e-Government initiatives, will provide an analysis of the services with a prospective evaluation of the technological strategies involved, while the qualitative and quantitative data in each case will help us analyse the quota and draw conclusions on the functionality and effectiveness of the services. We expect to evaluate the levels of digital growth and online adaptation of the Union and/or the need for further expansion. The study is discussing EU's technological competiveness and the analysis targets the policy initiatives taken towards this direction, while it provides multipolar, but useful information for EU citizens and businesses.

Keywords: Technological Revolution, Information, Communication, Digital Agenda, e-Government

\section{Introduction}

Constantly changing technologies are challenging for the existing social structures and this includes social policies and unquestionably involves civic society. European policies have turned their focus on growth with a relative delay, if one considers the contemporary challenges it has to face. Within these challenges, Europe needs to ensure economic growth that will lead EU countries and citizens out of crisis. According to Neelie Kroes, the European Commissioner for Digital Agenda, internet is the best platform to provide occupation nowadays (Rial, 2012). Digital technologies and, of course, the internet have become the economic foundation of modern societies, contributing to the world's developed economies in the late decades. As a matter of fact, consulting groups estimate that the internet economy will be responsible for G-20's impressive GDP increase by 2016 (Mettler, 2012a). These figures emphasize the increasing importance of digital developments and its economic value.

Mostly being a niche policy matter in the past, the 'digital agenda' has recently received the attention of heads of EU government and EU finance ministers. In recognition of the transforming qualities that general-purpose technology features for the economy, EU is called upon the target to bring the digital single market in life. This is not without reason since in Europe's most advanced economies, the internet accounts for a substantial lump of GDP (Mettler, 2012a). Consequently, it has become crucial for EU to approach internet governance and within this goal there are two aspects to be considered. On the one hand, public authorities, which ought to enforce the law and protect citizen rights. On the other hand, an attention should be given to the internet's restrictive framework, so that the latter does hamper the prospect for innovation (Europa, 2012). This is to say that an effective management of the digital vision can help overcoming the euro-crisis and direct to the next digital revolution, where Europe can 'be in the lead' (Europa, 2012). As Europe rediscovers the need for development, it is now vital to take account of new economic realities that clearly demonstrate that productivity, jobs and innovation come from greater adoption of digital technologies (Mettler, 2012b). In order to secure the aspects of this political direction, the EU has introduced a number of political tools, which facilitate the regulating, political and investing role of the 
ISSN 2411-9563 (Print) ISSN 2312-8429 (Online)
European Journal of Social Sciences Education and Research
September-December 2014

Volume 1, Issue 2

Union in this context. The Body of European Regulators for Electronic Communications (BEREC), the Digital Agenda and its goals and the e-Government platform are three initiatives representative of the direction EU has launched, in turn, to achieve technological growth. These three initiatives will serve as case studies in our article and help analyse the digital services from a critical perspective. The article is divided as follows: the first chapter is occupied with the regulating function of the EU and the practical role of BEREC as a regulative body. The second chapter will look into the EU's economic strategy with a focus on the Digital Agenda goals and initiatives. In sequence, the third chapter will explore EU's activity to maximize information technology's use among the EU states, taking e-Government as an example of technological capitalisation. Ultimately, the article is discussing EU's technological vision as much as the potential for technological innovation, which is extremely of useful not only for EU business but EU citizens as well.

\section{Regulating the European Telecommunications Market}

Europe's proclaimed need for innovation and competitiveness did not coincide with the financial crisis but was further accelerated to achieve growth and create new jobs in the member-states. The opening-up of the telecommunications market to competition has acted as a catalyst on a sector that was previously occupied by oligopolies (such as Deutsche Telecom and Vodafone). As the internet has developed over the past decades to an open platform with limited barriers for users, content and application and internet service providers, there was a need for a regulatory framework that would promote consistent practices among national regulatory authorities. To keep pace with the new conditions, EU institutions have initiated legislation according to the technological progress and market requirements. These developments have given rise to the adoption of the new regulatory framework on electronic communications, which aims at strengthening competition by facilitating market entry and motivating investments in the sector, according to the Directive 2002/21/EC.

The political objective was met through Directive 2002/21/EC adopted in 2002, which built on the framework for the regulation of electronic communications networks and services. This has also included certain aspects of terminal equipment to ease access for users with disabilities. The Directive 2002/21/EC contained provisions serving in the scope of principles, basic definitions, structural conditions for the national regulatory authorities (NRAs), the definition of the new marker power, rules for communication resources. In response to the need for inclusive regulation for all infrastructures, the new framework was extended to all electronic communication networks and services. Finally, a requisite of the Directive was the subsequent adoption of national measures in terms of access to electronic communications from the memberstates, with the intention of respecting the fundamental rights and freedoms of natural persons.

The 2002 telecoms regulatory framework in the EU has been surrounded by debates concerning its timely relegation and performance within the EU member-states. Moreover, it has questioned existing EU administrative policies and imposed modifications on policies, due to the rapid evolution of technologies combined with the socio-cultural diversity of Europe today (Tsatsou, 2011). As a result, the Body of European Regulators for Electronic Communications (BEREC) was established in 2009, by a regulation of the European Parliament and the Council. BEREC replaced the European Regulators Group for electronic communications networks and services, which functioned as an advisory group to the Commission since 2002. In this first chapter of the article, a brief description of the services provided by the official body, in relation to the regulatory framework is presented.

\section{The Body of European Regulators for Electronic Communications}

BEREC was launched as a part of the 'Telecom Package', a review of the EU telecommunications framework in 20072009. The review aimed to achieve the much needed update of the EU telecoms framework established in 2002 and put a common set of regulations for the industries involved across the EU member-states. The objective of the body is mainly to contribute to the functioning of the internal market for electronic communications network and services, as well as to enhance cooperation among National Regulatory Authorities (NRAs) and to strengthen the internal market in electronic communications networks, according to the Regulation No 1211/2009. For the fulfillment of this goal, the Regulation No $1211 / 2009$ provides that the body will develop and disseminate among NRAs regulatory best practices, such as successful methodologies or guidelines on the implementation of the EU regulatory framework, deliver opinions on draft decisions and recommendations, issue reporting and provide advice on the electronic communications sector, and assist the European Parliament, the Council and the Commission, as well as NRAs in the dissemination of best practices.

The greater difference between BEREC and the ERG (European Regulators Group) lays in the way they were established. BEREC was established by a Regulation of the European Parliament and the Council of the European Union 
ISSN 2411-9563 (Print) ISSN 2312-8429 (Online)
European Journal of Social Sciences Education and Research
September-December 2014

Volume 1, Issue 2

and not by a Commission decision. This highlights the 'institutionalised' identity of the body and reflects the desire to accord an 'elevated status' to the new body (Batura, 2012). While the ERG's aim was to contribute to the development of the internal market, BEREC shall pursue the same objectives as the NRAs, which include promotion of competition and promotion of interests of the EU citizens, as provided in Regulation No 1211/2009. This also reflects the ambition to intensify the new institution's status beyond a merely consultative role. At the same time, it unleashes the possibility to enhance its tasks and powers in the future.

The structure of the body is based on the rule of representativeness; the board of regulators is composed by the heads of representatives of the NRAs established in each member-state, with primary responsibility to oversee the day-to-day operations of the national markets for electronic communications networks and services. The board of regulator will be assisted by the office, which includes a management committee and an administrative manager. The members of this committee are selected among the board of directors, additionally to a member representing the commission, according to Regulation No 1211/2009. The tasks of the board are not few, including publishing opinions on NRAs concerning market definitions, the description of undertakings with significant market power and the imposition of remedies as well as collaboration with NRAs in this context; the consultation on draft recommendations on relevant product and service markets; publishing opinions on draft decisions on the identification of transnational markets and the development of common rules and requirements for providers of cross-border business services; consultation on draft measures relating to effective access to the emergency call number 112, and the effective implementation of the 116 numbering range; monitoring and reporting on the electronic communications sector, and publishing an annual report on developments in that sector. Regulation No 1211/2009 also provides that the office assists with administrative support services or collects information from NRAs, as well as disseminates the regulatory best practices among NRAs.

The creation of BEREC was accompanied by a lot of controversies and debates regarding its necessity, defined institutional nature, competences and functions and influence on the market. And while the above are clarified in the regulation establishing BEREC, and BEREC is dynamically carrying out its tasks since January 2010, one can try to examine the institutional influence in the market or research the place BEREC actually holds in the European regulatory network (Batura, 2012). The regulatory environment of electronic communications hosts various authorities, which apart from the European Commission (EC) and national regulatory authorities includes comitology committees (e.g. Communications Committee), standard-setting organisations (e.g. European Telecommunications Standards Institute), European Network and Information Security Agency (ENISA), competition authorities etc. At the opening ceremony for the BEREC office in Riga, Neelie Kroes spoke of BEREC's 'crucial role' in the development of a 'digital Single Market' (Europa, 2011). Accordingly, Dr. Georg Serentschy, former BEREC's Vice-Chair, argued at the conference of Florence School of Regulation in June 2011 that BEREC is a key player in development of the single market for electronic communications (Serentschy, 2011). However, some researchers have allegedly argued that BEREC is fundamentally the same with its precedent organisation with only limited modifications compared to the European Regulators Group (Cave et al, 2009). Considering ERG's reputation as a fairly inefficient and non-transparent body, those critics do not allow the recent institution creation to flourish and decrease the optimistic prospective of its central role in the regulatory network (Batura, 2012).

Although BEREC has initiated its operation since January 2010, it has been considerably active in comparison to ERG, considering the number of documents adopted since 2010. The number of various documents adopted by BEREC in the first 2 years amount almost the number of all documents adopted by ERG during 7 years, i.e. 110 publications (Batura, 2012). Also, BEREC displays an activism independent from the article 7 procedures, producing various studies and collecting information. Thus, it can be safely said that BEREC has been using all its powers, in order to demonstrate an active expert position and become a central actor within the network of telecommunications regulation. Going back to the statements about BEREC's regulatory significance in electronic communications, it is arguable that they more or less correct, if taken in a more conditional way. BEREC's involvement in regulation varies significantly at national levels. Thus, BEREC is mainly involved in the process of policy-making at the EU level, while at national level it is involved in their implementation of the policies and the regulatory activity. BEREC's widespread operational success implies that the balance between the EU and national authorities has been properly set. Without a doubt, it has become clear that "the pursuit of the single market is best served by increasing the quality of regulation across individual national markets" (Bustani, 2014). 
ISSN 2411-9563 (Print) ISSN 2312-8429 (Online)
European Journal of Social Sciences Education and Research
September-December 2014

Volume 1, Issue 2

\section{The Situation in Numbers}

The main goal of the European Commission's regulation of the telecommunication networks is to empower all EU citizens in the digital single market by providing an open internet. On this basis, European consumers and businesses will be able to experience the advantages of the digital market, which might result in an increase in demand in digital services. "Providing end-users with access to affordable and good quality digital services throughout the EU is the foundation. This can be achieved through enhancing competition and maximising end-user benefit" (Europa, 2012). A look into BEREC's work helps us understand the environment within which telecommunications companies function; the types of markets and restrictions within they operate, as well as the respondent operators.

Graph nr. 1: Market types according to restrictions, Graph nr. 2: Fixed Market Types - Restrictions, Graph nr. 3: Mobile Market types - Restrictions and Graph nr. 4: Mobile Markets - Restrictions, all available at the end of the article, explain how the market factors operate: a) national markets are sorted on the basis of the share of user clients of operators, who restrict the considered application for all, some or one of their users; b) three groups of markets are formed, on the basis of categories described before (all $>50 \%$, none $>50 \%$, others); $c$ ) the size of each group (number of countries) guides to the distribution (in percentages) of types of markets, in terms of number of countries, $d$ ) weighting each national market by its number of subscribers, leads to the distribution (in percentages) of types of markets, in terms of number of subscribers.

The results of the BEREC investigation on internet traffic management practices reveal numerous problems. More than $36 \%$ of all mobile users and more than $21 \%$ of all fixed network users in the EU are affected by restrictions on peer-to-peer traffic, at peak times. The effect of that can reach up to $95 \%$ of users in a country. Additionally, more than $21 \%$ of all mobile users are affected by restrictions on VolP (Voice over Internet Protocol) traffic and $12 \%$ by restrictions on other specific traffic. At the same time, most internet Service Providers (ISPs) in nearly all member-states, offer fixed and mobile internet access services that are not subject to restrictions. According to the BEREC findings, $85 \%$ of all fixed ISPs and $76 \%$ of all mobile ISPs propose, at least, one unrestricted offer, while there is a lack of transparency which incommodes users, in their effort to choose the offer that covers their needs. Indeed, end-users might not know how their operator affects their internet traffic (European Commission, 2012b). In consequence, switching providers, which intensifies competitions and enhances the desired openness, faces operational difficulties. Therefore, it has become clear that new measures need to be adopted to maximise EU citizens' activity in and benefits from the single market for converged telecoms, networks and services, particularly by maintaining the internet open to access, according to their choices.

\section{Europe's Economic Strategy}

The European Commission set out in 2010 the new strategy for stimulating the European economy, shedding a vision of 'smart, sustainable, inclusive' growth, which is based on wider coordination of national and European policy (European Commission, 2010b). Following one of the most serious declines of the European economy, 'Europe 2020' aims to embrace the challenges ahead. The economic crisis has revealed the weaknesses of a globalised economy, which has exposed limited resources and ageing population. The commission is looking to get behind an innovative, greener and social market that will facilitate an economic recovery and a more sustainable future. The strategy promotes low-carbon industries, investing in the development of new products, with a focus on digital economy and modernised education (European Commission, 2010b). The growth strategy set forth by the European Council has to overcome not only the severe obstacles of the financial and political debt crises in Europe, but the austerity policies as well, which have been imposed across many EU member-states (Stassinopoulos, 2013). The macro-economic policy making that has been forced on many European governments by the 'Stability and Growth Pact' has questioned the ability of this policy-mix to fulfill the goals set in the Agenda 2020, but also for the capacity of European governance to address the major discrepancies within the EU (Organisation for Economic Cooperation and Development, 2011).

In the technological front, although Europe is one of the most educated societies, it features a considerable deficit in the research field. According to the Treaty of the European Union, EU countries spend 1.9\% of GDP for Research \& Development (R\&D), while the U.S., Japan and South Korea are reaching the $3 \%$ performed in the industrial sector. Specifically, the United States research is about 2.6\% and Japan 3.4\% (European Commission, 2013). While the Lisbon Treaty has originally set the direction towards research and development (R\&D), no particular direction was given. The Lisbon Strategy's revision aimed, among others, at the establishment of investment in knowledge and innovation (Euractiv, 2009). During the past years, the European Union has made progress in order to meet the R\&D intensity target. The EU $3 \%$ target and additional national targets have mobilised growing resources for R\&D. "The national 2020 R\&D targets, set up by Member-States in 2010, are ambitious but achievable and would bring the EU R\&D intensity to $2.7-2.8 \%$ of GDP in 
2020, close to $3 \%$ in 2020" (Stassinopoulos, 2013). One of the seven flagship initiatives is the 'Digital agenda for Europe', which aims to speed up the roll-out of high-speed internet and bring in the benefits of a digital single market for households and business.

This chapter follows the priorities and targets set in the Europe 2020 agenda, which fall under research and development and regard specifically the 'digital agenda' and the scope for the digital single market. Our aim is to record the progress initiated in the area of Information Technology. This approach not only emphasises in the implication of the Digital Agenda in economic growth, but also examines the social expansion of the digital sphere through a path that is not only sustainable, but also widely acceptable by the European people.

\section{The Digital Agenda for Europe}

The need for immediate action across the digital policy areas has been underlined by many institutions. Europe was in need of a new economic momentum to help its economies to exit from the financial crisis and reconstruct their competitiveness (European Policy Centre, 2010). Especially, the economies of Central and Eastern Europe could provide a large market in fields and sectors where they could potentially develop their competitive advantage. Neelie Kroes has recently underlined the need to place ICT in the centre of EU policy-making; "not because it is a goal itself, but because it is the means to other goals", health, education, inclusive growth, gender quality and many more (European Commission, 2014). The Vice-President of the European Commission emphasised connectivity in Europe is directly linked to 'inclusive infrastructure' and has to be $100 \%$ accessible to Europeans, as without it the 'digital idea' becomes an unattainable goal. To strengthen Europe's knowledge economy and drive into future growth, investment has to be focused where the economic impact is biggest, in the digital market. More specifically, the dispersion of digital technology is the key to Europe's competitiveness (Business Europe, 2011).

The Digital Agenda contains 101 actions, in 7 pillars, which will help to revive the EU economy and reinforce the position of digital technologies among Europe's citizens and businesses (European Commission, 2010). The first pillar aims to synchronise the EU Single Market with the digital era, creating a Digital Single Market with limited barriers in the free of online services. The second is occupied with interoperability and standards, ensuring that new IT devices, applications and services interact without obstacles anywhere in Europe, while the third pillar wants to create a safe environment for online transactions (trust \& security). The fourth pillar works towards a faster internet access available in Europe ( $30 \mathrm{Mbps}$ for all of its citizens and at least $50 \%$ of European households subscribing to internet connections above $100 \mathrm{Mbps}$ by 2020), to match world leaders like South Korea and Japan. The fifth pillar is working through the creation of a leading research and development market (R\&D), world class infrastructure and sufficient funding, while the sixth pillar aims to enhance digital literacy and digital inclusion. Finally, the seventh pillar focused on the promotion of the ICT benefits for the European society (European Commission, 2010). Focusing on the Digital Single Market in this chapter, we will be able to evaluate the digital vision of the European Union through the assessment of digital expansion policies.

A Digital Single Market could be extremely helpful in addressing a wide range of Europe's current socioeconomic problems, due to the innovative character of the market. It could also potentially help to make Europe's labour markets more efficient and at the same time more social, while it would direct Europe into a low carbon economy. So what is the Digital Single Market? The first Pillar of the Digital Agenda, under Digital Single Market, stands for a new vision of online expansion. The numerous barriers blocking online services and entertainment across national borders underlined the necessity of updated EU rules to enter the digital era. These further targets at the reinforcement of the music download industry, the online payment systems and the extensive protection of EU consumers in cyberspace (European Commission, 2010). The target is that Europe gains $4 \%$ of GDP by fully developing the digital single market by 2020 . This would interpret to a $€ 500$ billion gain, meaning that the digital single market could have an impact similar to the 1992 Internal Market programme (Business Europe, 2011).

The vision of the European Commission upon completion of the Digital Single Market involves the enhancement of the EU legislation, in order to ameliorate the framework conditions for growth and jobs. Through the European Commission's Directorate General for Communications, Networks, Content \& Technology (DG Connect), the EC aims to coordinate the policy initiatives that will lead directly to the completion of the Digital Single Market (European Commission, 2014). With 28 separate actions, the EC target at a digital economy that will potentially provide a major boost to EU productivity and growth. It is estimated that at least 4 percent additional GDP (EU27) could be gained in the longer run, by stimulating further adoption of ICT and digital services through the creation of a DSM (MICUS, 2008). This impact of the DSM is based on two aspects: the impact of improved physical infrastructure and improved e-readiness on the engagement of online services. 
ISSN 2411-9563 (Print) ISSN 2312-8429 (Online)
European Journal of Social Sciences Education and Research
September-December 2014

Volume 1, Issue 2

The combination of improved infrastructure and increased e-skills can cause an increase in the use of online services of $3 \%$ per year. This generates two effects: structural change in the EU economy and improved productivity in all sectors (ECORYS, 2011).

The mid-term review presented in 2012 noted that regular internet usage has increasingly augmented in the first two years of the pillar, especially among disadvantages groups. At the same time, online commerce follows a continued increase, despite the fact that cross-border increase remains slower. High-speed broadband is beginning to take off, including ultra-fast connections above $100 \mathrm{Mbps}$ (European Commission, 2012). As always, significant differences remain among different Member-States, differences which require the EU's action in order to minimise and eliminate (European Council, 2012). The following chapter provides important comparative data on the implementation of the DSM pillar across the EU member-states.

\section{Digital Single Market in numbers}

It appears that the online trends are continuously changing during the past five years. The most recent online services index have grown continuously in the past few years, from $5.1 \%$ in 2009 to $6.2 \%$ in 2013 , showing that as people become more experienced and confident online, they increase the frequency of use, as well as the diversity of activities. This process takes time, and while leading countries such as Denmark and Sweden are about 4 years ahead of the EU average, internet users in countries such as Romania, Bulgaria, Italy and Poland are 4 years behind the average in terms of diversification of their online behaviour. The Graph Nr. 5: Activities performed online by internet users, a comparative graph, indicates the use of internet services in EU28, while the index was calculated on individual use based on the below parameters: sending/receiving e-mails, browsing for information about goods and services, reading online newspapers/news, looking for information on travel/accommodation services, posting messages to social media, interacting with public authorities, internet banking, telephoning or video calls, selling goods or services, purchasing content (films, music, software), purchasing goods, purchasing services.

The trend towards online shopping has also presented a significant increase. The proportion of online shoppers continued to grow, more than 10 percent between $2009-2013$ for the $47 \%$ of the citizens. Therefore, the digital agenda target of $50 \%$ by 2015 is likely to be achieved. While there appears to be no overall relationship between the rate of online shoppers in a country and the rate of increase in this rate over the period observed, the countries with the lowest rates of online shoppers (Romania, Bulgaria, Italy and Estonia) have experiences the smallest progress in increasing rates. Crossborder online shopping has also increased over this period, up to $12 \%$ in 2013 , but this pace is too slow to achieve the target of $20 \%$ by 2015 . Usually, smaller member-states have higher rates of cross-border shopping. In Poland only, $9 \%$ of online shoppers purchased cross-border, the lowest share of all member-states by far (European Commission, 2014a). The Graph Nr. 6: online shopping trends by citizens, demonstrates the comparative increase of online shoppers between 2009 and 2013.

The revenues from advertising are in much slower recovery after the EU financial crisis. Online and mobile advertising are an exception since they demonstrate a much faster recovery than the advertising sector as a whole. Online advertising is, at the moment, overtaking traditionally dominant sectors in terms of revenue share. The financial crisis caused a brutal decline in advertising, but recently advertising revenues have slowly started to recover. Total advertising revenues reached 75.593 billion in 2013 , which advertising still represents $87 \%$ of the 2007 pre-crisis peak value. Revenue for the whole advertising industry returned to positive growth in 2013 , mainly due to the online and mobile segments. In 2013, revenue from traditional segments decreased $5 \%$, while the Online + Mobile segments grew $18 \%$. Online + Mobile advertising revenue shares have grown gradually since 2005 . At 23 billion in 2013 , they accounted for over $30 \%$ of total advertising revenue. By contrast, the revenue shares of the Print and TV segments have declined, and are about to be overtaken by the online segment. The Graph Nr. 7 and Nr. 8: Advertising Revenues, according to the type of media, showcases the segment occupied by the media types over the past decade and the share of advertising revenues, based on the type of media.

The Digital Agenda for Europe set three major targets on broadband: basic broadband networks should be available to all EU citizens by 2013 and by 2020 half of European households should subscribe to at least $100 \mathrm{Mbps}$, while $30 \mathrm{Mbps}$ should be available to all Europeans (European Commission, 2014a). The data about basic broadband coverage show that basic broadband is available to everyone in the EU, while fixed technologies cover $97 \%$ leaving 6 million homes unconnected. Next Generation Access (NGA) covers $62 \%$, increased when compared to $54 \%$ a year ago. Rural coverage still remains significantly lower, according to Graph Nr. 9: Technological coverage at EU level. Basic broadband is available 
ISSN 2411-9563 (Print) ISSN 2312-8429 (Online)
European Journal of Social Sciences Education and Research
September-December 2014

Volume 1, Issue 2

to all member-states in the EU, when considering all major technologies (xDSL, Cable, Fibre to the Premises, WiMax, HSPA, LTE and Satellite). Taking only fixed, fixed wireless (WiMAX) and mobile wireless (HSPA and LTE) into account, the coverage goes down to $99.4 \%$. Fixed and fixed-wireless technologies cover $97.2 \%$ of EU homes. Next Generation Access technologies (VDSL, Cable Docsis 3.0 and FTTP) capable of delivering at least $30 \mathrm{Mbps}$ download are available to $62 \%$. Coverage in rural areas is substantially lower for fixed technologies $(89.8 \%)$, and especially for NGA $(18.1 \%)$.

As a whole, it appears that indeed the digital market is gradually taking over traditional market segments, while the use of internet has significantly increased during the past five years. As the 2013 target on broadband is mostly achieved, the Digital Agenda has an obvious focus on migration to faster speeds now. In the next chapter, we will see how the EU is utilizing the telecoms sector to provide quality e-government services to EU-citizens.

\section{Maximizing the use of information technologies in Public Administration}

The introduction of ICT in public administration has created numerous opportunities for more efficient and dynamic work, providing the chance for innovation and better delivery of public services. The Lisbon Strategy for Growth and Jobs in 2000 created a new focus on achieving growth and sustainability for both the European Union and its member-states. The objectives of the Lisbon strategy aimed at the strengthening of European economies and employing the benefits of globalisation to cope with contemporary challenges: ageing populations, learning issues, environmental and sustainability challenges, competitiveness and efficiency, as well as technological challenges (Archmann \& Iglesias, 2010). Therefore, EU institutions have recognised the importance of investing in the development of eGovernment and ICT, given the central role of these technologies in supporting the current trend in both public and private sectors. As a result, public administration has been required to take a leading role in innovation, promoting more dynamic and efficient working methods and higherquality service eGovernment - a significant step towards innovation and efficiency in Public Administration in all EU member-states.

The increasing use of ICT has led public administrations across Europe to engage in severe transformation procedures, which aim at achieving a more efficient, friendly, citizen-and business-centric delivery of public services. The approach is known as "Transformational Government" and it has become a driving force for innovation and reduction of administrative burdens in European public administration. The Web 2.0 applications provide millions of possibilities that public services could benefit from (Archmann \& Iglesias, 2010). While, though, the opportunities offered are enormous, there are also challenges to address in the implementation of such processes, such as ensuring digital access for all citizens (through expanded internet provision) and taking into account all dimensions of the sharing of governmental information across Europe. Public administration also has to adopt a new, market-oriented approach to the delivery of public services that minimises bureaucracy and reduces the administrative burden for citizens and businesses, thus enhancing their satisfaction and increasing the efficiency and effectiveness of public administration back-office functions.

\section{The case of e-Government}

The trends towards eGovernment have considerable changed during the past five years. Following an enumeration of statistical date from 2009 to 2014, we are able to follow through the swift in eGovernment services use. The 2009 Eurostat data revealed a gap between the different member-states which had to be taken into account, as well as the gaps in the use of ICT between different age groups, people with different levels of education and computer literacy, between people from rural/urban areas and between genders. According to Eurostat (2009), the use of ICT was close to $56 \%$ of the European Union's citizens. These figures also highlighted the diversification of these rates, which reached nearly $90 \%$ in countries such as the Netherlands, Denmark and Finland, while being between $30 \%$ and $35 \%$ in others, including Greece, Romania and Italy (Eurostat, 2009). The statistics also showed that barely $28 \%$ of the citizens of the EU-27 used the internet to interact with public authorities, in the last three months of 2009 , and that there was a marked difference between memberstates. Despite keeping a correlation with the use of the internet in private life, the rates of use for interaction with public authorities are lower, reaching a peak of $55 \%$ in countries such as the Netherlands and Finland, and only $5 \%$ and $10 \%$ in countries such as Greece, Romania and Bulgaria (Eurostat, 2009). The Graph 10, Regular users of the internet in the last 3 months of 2009 , demonstrates these rates.

The latest 2009 statistics on eGovernment highlighted the importance of elnclusion (digital inclusion) and enhanced the commitment to achieve substantial improvements by 2015. EU governments need to 'to empower businesses and citizens through eGovernment services designed around users' needs, better access to information and their active 
ISSN 2411-9563 (Print) ISSN 2312-8429 (Online)
European Journal of Social Sciences Education and Research
September-December 2014

Volume 1, Issue 2

involvement in the policy-making process' (European Commission, 2009). As a result, the European Commission has launched an ambitious programme to promote inclusion under the name 'No Citizen Left Behind', which aimed to foster elnclusion in all segments of population, paying special attention to the risk groups: people who reside in remote areas, people with physical impairments and the elderly (Blixt, 2010). Additionally, the programme promoted the development of infrastructures and internet connection availability in any location within the EU, through broadband connection and mobile access (Blixt, 2010).

The Europe 2020 strategy introduced an ambitious agenda to exit from the economic crisis and to create a smart, sustainable and inclusive Europe that will be able to compete globally, across sectors. Improvement on numerous domains can be accelerated by better use of Information Technologies (ICT). ICT has proven to be a powerful tool to include people in society, e.g. the 'Arab Spring' could not have happened in the way it did without social media (Allagui, 2011). Mobile communications technology and applications enable citizens to access information and services anywhere. Thus, technology empowers citizens, not only among, but between people and governments.

Governments can more easily exchange data and therefore inform citizens and businesses, and better engage them in policy development, democratic decision-making and co-creation of services and content. Alongside benefits for citizens, ICTs offer significant advantages for governments themselves. Smart use of data can provide governments' with valuable information to anticipate trends, combat crime, or increase the effectiveness of public services. Importantly also, technology can be used by governments to significantly reduce costs, cause transform and innovate. To enable European citizens, businesses and governments to fully benefit from this digital revolution and to address current societal and economic challenges, governments must actively anticipate and exploit technological developments. To be part of the global economy of the future, they not only have to work towards a European Single Market, but towards a European Digital Single Market, the elements of which we examined in earlier chapter (European Commission, 2012c).

The seven flagship initiatives of the Europe 2020 Strategy include the Digital Agenda for Europe (DAE), which specifically addresses the need for effective use of ICT based on fully operational applications that will deliver social and economic benefits. The targets set by DAE for eGovernment are translated into specific actions for the EU governments in the European eGovernment Action Plan 2011-2015. The resulting eGovernment Action Plan focuses on four areas: 1) Empowerment of citizens and Businesses; 2) Mobility in the Single Market; 3) Efficiency and Effectiveness of governments and administrations; 4) Legal and technical preconditions. Actions are set out for each focus area and help governments deploy ICT in order to utilise public resources more efficiently, reduce public expenditure and provide digital government services across Europe.

Though promising vast benefits for governments and the society in general, the first survey conducted (online) on eGovernment services in Europe in 2012, revealed only one of two EU citizens is using eGovernment services, while user satisfaction for public online services lags behind the private sector (European Commission, 2012c). The European Commission released in 2012 the 10th Benchmark Measurement of European eGovernment Services, according to which availability of eGovernment services in the first two years was generally high, usage and satisfaction still needed improvement - particularly when compared with private eServices. Simplicity, time saving and flexibility are the key reasons citizens prefer to use eGovernment services. Ninety-three percent of the citizens, who used online services were fully or partially satisfied with what they received. Respondents from the 32 participating countries indicated that the barriers to adopting eGovernment services were difficulties in usage (24\%), and lack of awareness (21\%). Many citizens are still unwilling to use eGovernment services $(80 \%)$, and indicated a strong preference for personal contact (62\%), and/or expect that offline contact is required anyway (34\%), and/or believed other channels to be more effective (19\%). Interestingly, concerns about protection and security of personal data were only modest, at $11 \%$. The Graph Nr. 11, Key insights user survey in all EU-27 (2010-2012), featured the relevant data.

Public services are increasingly becoming aware of the significance of information technologies. Although progressively used, the services leave room for improvement in many areas, which lead users to undervalue the effectiveness of online public services. According to the 11th eGovernment Benchmark report, noteworthy progress has been highlighted in the following four areas: a/ user centricity (online availability and usability), b/ transparency, c/ cross border mobility and $\mathrm{d} /$ key enablers. On the one hand, online availability, which relates the existence of electronic channels for public services, is at 72 percent on average in the EU. Online usability, on the other hand, is 78 percent on government websites, even though ease and speed of use are at 58 percent, which leaves room for improvement. Online usability attempts to rate the overall experience by assessing usability features, including functionalities, support, feedback etc (European Commission, 2014b). 
ISSN 2411-9563 (Print) ISSN 2312-8429 (Online)
European Journal of Social Sciences Education and Research
September-December 2014

Volume 1, Issue 2

As far as transparency is concerned, the extent to which governmental platforms are indicated as fulfilling their responsibilities and performance reached only 48 percent. It is estimated that the low EU score was due to insufficient information provided to users about eGovernment services. However, the transparency levels are slightly higher when it comes to provision of institutional information about the administrations, or information concerning the personal data involved in service delivery (European Commission, 2014b). It is, though, undeniable that there is a long way to go in order to achieve a fully open and transparent public e-service of organisations. When it comes to cross border mobility, the report showed that EU governments have not yet achieved to give businesses and citizens ample access to online public services, when they are away from their home country. Availability of cross-border public services remains at 42 percent, 30 percent points lower than availability of public services for country nationals. "Transactional services - these services where an electronic transaction between the user and the public administration occurs - are possible only in very few cases, causing unnecessary burdens for citizens and businesses that want to move, work or start up in another EU country" (European Commission, 2014b). Graph Nr. 12: eGovernment performance according to policy priorities, shows that the key enablers indicator measures the availability of technical elements, essential for public services, such as electronic identification (elD), electronic documents (eDocuments), authentic sources, electronic safe (eSafe) and single-sign-on (SSO). Technical elements, along with technical approaches, are critically important in order to set up seamless online services. According to the report, key enablers are implemented in less than half $(49 \%)$ of the cases where they could be used.

The report summarizes the key findings from the recent survey as: a) considering that every European citizen had internet access combined with the skills to use it, there is still a noteworthy group of non-believers (38\%) that refuse to use the online channel for public services, and $b$ ) this is mainly due to users' expectations driven by their experience with private service providers (online banking, for example) and online public services do not admittedly live up to those expectations. In response to the gaps featured at the implementation of eGovernment services, the European Commission is looking to engage the members-states in the promotion of an Open Government approach. This perspective includes opening their data and their procedures in order to provide better and cost-effective services, create jobs and growth in their countries. The open government approach also allows citizens to participate in the design, creation and delivery of digital services and contribute with their opinion in the improvement of the services. Horizon 2020 and Connecting Europe Facility will support the Open Government approach in the future (European Commission, 2014b).

\section{A review of the EU telecommunications framework}

The most important milestones have already been achieved by the work of the EU institutions, driven by the 'Digital Agenda for Europe'. Moreover, the fact that the Greek Presidency of the Council of the EU (January - June 2014) has placed ICT among its priorities constitutes already a promising first step. Moving to data, according to the Digital Agenda Scoreboard, published in May 2014, EU citizens and businesses are going online more, shopping online more often and have better skills in ICT. This is part of the new data of the Digital Agenda Scoreboard from 72 completed Digital Agenda actions out of 101 (European Commission, 2014a). In general, the results are considered by far positive. The internet usage has increased and continues to increase rapidly; now stands at $72 \%$, from $60 \%$ that it was initially (2009). Progress has been even faster among disadvantaged groups, as well. Additionally, online shopping is progressing, arriving at $47 \%$ and 10 points up from the start of the DAE. Lastly, high-speed broadband is now available to $62 \%$ of the population, more than twice the $29 \%$ it was demonstrated in 2010 . Still, progress so far has been heavily concentrated in urban areas. Given the limited advancement in rural areas, it is perhaps too early to judge whether the 2020 broadband targets will be reached. The Graph Nr. 13, Progress report 2009-2013, offers a total impression of the targets already met within the last four years.

However, few areas demonstrated a much slower progress. The area of eGovernment, to start with, which was examined in earlier chapter, added only four points over four years. This indicated a very slow growth compared to other online applications and is has indeed caused stagnation to a number of countries (Spain, Portugal, Hungary) (European Commission, 2014a). There has been considerable progress in many countries, but very slow change or even decrease in several large member-states (Italy, Poland, United Kingdom, Germany), which means that the EU average has been moved but in a limited scale. Obviously, neither the potential savings in administration costs nor the potential benefits to citizens are fully exploited. Secondly, the eCommerce sector offered a surprise in numbers. A plain $14 \%$ of SMEs used the internet as a sales channel, only two points up in four years. With such low rates, eCommerce can only be very limited tool for SMEs to grow and create jobs. The share of SMEs purchasing online is generally much higher, and the EU average of $26 \%$ is much closer to the target. This relative success is partly due to a much higher starting point. Thirdly, public support for 
ISSN 2411-9563 (Print) ISSN 2312-8429 (Online)
European Journal of Social Sciences Education and Research
September-December 2014

Volume 1, Issue 2

Research \& Development (R\&D) in ICT is well below the annual growth needed to achieve a targeted doubling by 2020; budget deficit reductions have taken their toll. The target of doubling public R\&D by 2020 requires an annual growth rate of $5.5 \%$. Already last year actual performance was below the necessary trend line; now the gap is about $20 \%$. And finally, cross-border shopping has been growing only slowly. Cross-border online shopping has also increased somewhat over this period, up to $12 \%$ in 2013 , but this pace is too slow to achieve the target of $20 \%$ by 2015 . As could be expected, smaller member states have higher rates of cross-border shopping. However, they also exhibit higher growth. In Poland only $9 \%$ of online shoppers purchased cross-border, the lowest share of all member states by far.

In this challenging context, policies and regulation play a key role to keep pace with market and technology developments. The main target of EU policy-makers should be to shape a policy environment that attracts private investments. The first half of the year 2014 offered a great opportunity for EU to speed up its effort towards building a Smarter Europe and the Greek presidency work on the mid-term review of the 'Digital Agenda for Europe' has set ambitious vision for the future, according to Luigi Gambardella (Euractiv, 2014). The IP traffic was flourishing at a high pace (19.6 exabytes/month) and we should expect to see it growing in the coming years. In 2016, it is expected to reach 30.3 exabytes per month, according to Cisco's figures (Cisco VN1, 2012). These numbers and their impressive scale are foretelling that the future will be more connected and that this trend should be embraced. In order to exploit the enormous opportunities associated with this evolution, in fields such as cloud, e-health, e-government and many others, Europe needs to count on a prosperous telecommunications sector. With both fixed and wireless networks, telecom operators comprise the digital backbone of Europe, carrying every day the communications of hundreds of millions of people, businesses and governments (Euractiv, 2014). The review of the current framework should not only set priorities as a revision of the rules existing in the communications sector; it should rapidly develop the ICT landscape and new services, in order to better respond to the changing environment.

\section{Conclusions}

This article looked into the rapidly changing Information Technology landscape of Europe, with a focus on the 'digital agenda' of the EU that contributes to the expansion and development of the digital technologies. As Europe has discovered the need for technological development relatively recently compared to the USA, it became the centre of our study, through the recent adoption of digital technology-focused policies. Further studies can discuss the vision and social impact of European technology-focused policies in the future, especially in the areas that - as we saw in the article - lag behind in Europe.

A number of policies and bodies were examined in the present article, with three cases catching our attention. The Body of European Regulators for Electronic Communications (BEREC), the Digital Agenda with a focus on the Digital Single Market and the e-Government platform are three key initiatives towards the innovation and growth needed for EU to recover from the recent crisis. Analysing these three initiatives as case studies, with an amount of collective data in our disposal, it becomes easily understood that the direction towards technological growth is positive.

From a regulatory point of view, EU has been through an institutional change that helped to ameliorate the regulatory framework under which telecommunications have been functioning in Europe. It has become clear that the BEREC has set out a more active and resourceful schema to maximise networks and services' access. An important step towards internet open to all was made, even though the full range of activities converged telecoms have to offer are partly unexploited.

The economic strategy involving the EU Digital Agenda and its various targets has been designed with great prospects. All together, we observed, by the statistical data that the digital market has indeed developed over traditional market segments (such as traditional advertising or commerce), while the use of internet among people and business was increased. E-Government services have, finally, been studied as a form of maximization of technological use in public administration. In this area, the progress still lags behind considering other sectors, not only due to software features, but too often due to a lack of willingness and trust from the citizens.

Ultimately, the results demonstrate a considerable progress during the last five years, even though it seems impossible for some areas (e.g. e-Commerce, high-speed broadband, etc.) to meet their 2020 targets. What has, though, become clear is that for all digital fields to be properly exploited and developed, the EU needs to take the prospects of the telecommunications sector seriously. Additionally, the assessment of such services that will determine the future target should take into changing economic and socio-cultural environment within which EU policies operate, and not designed outside of it. The European Union should ensure that all reviews set an ambitious agenda to unleash further Europe's potential to invest and innovate at continental and global levels, and inspire creative leadership accordingly. 


\section{References}

[1] Allagui, I. (2011) The Arab Spring and the Role of ICTs. International Journal of Communication, 5, 1435-1442.

[2] Archmann, S. \& Iglesias, J. C. (2010). eGovernment - a driving force for innovation and efficiency in Public Administration. Retrieved from

[3] http://www.eipa.eu/files/repository/eipascope/20100519110452 Eipascope 2010 1eGovernment.pdf

[4] Batura, O. (2012, July). Regulatory networks: the role of BEREC in regulation of the common market for electronic communications. Paper presented at the 23rd European Regional Conference of the International Telecommunication Society, Vienna, Austria.

[5] BEREC (2012). BoR (12) 30 Annual Report. Retrieved from http://berec.europa.eu/eng/document register/subject_matter/berec/reports/45-berec-findings-on-traffic-management-practices-in-europe

[6] Blixt, P. (2006). Accelerating eGovernment in Europe for the Benefit of All [PowerPoint slides]. Retrieved from http://www.egov-zentrum.fraunhofer.de/extra files filedownload.php3?id=92

[7] Business Europe. (2011). Digital Single Market (Policy Briefing). Retrieved from http://www.businesseurope.eu/Content/Default.asp?PagelD $=673$

[8] Bustani, C. (2014, May 21). BEREC: Unleashing its Potential to Promote Europe's Single Market [Web log post]. Retrieved from http://blogs.Ise.ac.uk/mediapolicyproject/2014/05/21/berec-unleashing-its-potential-to-promoteeuropes-single-market/

[9] Cave, M., Haucap, J., Padilla, J., Renda, A., Williamson, B. (2009). Monitoring EU Telecoms Policy. Madrid: Network for Electronic Research on Electronic Communications.

[10] Cisco VN1. (2012). Cisco Visual Networking Index 2011-2016. Retrieved from http://www.cisco.com/c/en/us/solutions/collateral/service-provider/visual-networking-index vni/VNI_Hyperconnectivity_WP.html

[11] Directive 2002/21/EC of the European Parliament and of the Council on a common regulatory framework for electronic communications networks and services [2002]. OJ L108/33.

[12] ECORYS. (2011) Steps towards a truly Internal Market for e-communications. In the run-up to 2020 [Ref. Ares(2012)95105 - 27/01/2012]. Retrieved from http://www.ecorys.com/news/ec-study-towards-truly-internalmarket-e-communications

[13] Euractiv. (2009). Growth and jobs: Reshaping the EU's 'Lisbon Strategy'. Retrieved from http://www.euractiv.com/priorities/growth-jobs-reshaping-eus-lisbon-linksdossier-188511

[14] Euractiv. (2014). A New Agenda for a Smarter Europe. Retrieved from http://www.euractiv.com/infosociety/newagenda-smarter-europe-analysis-532860

[15] Europa. (2011). Opening Europe's telecom markets - BEREC's crucial role [Press Release]. Retrieved from http://europa.eu/rapid/press-release_SPEECH-11-666_en.htm

[16] Europa. (2012). A European vision for Internet governance [Press Release]. Retrieved from http://europa.eu/rapid/press-release_SPEECH-12-444_en.htm?locale=en

[17] European Commission. (2009). Malmö Ministerial Declaration [Electronic Version]. Retrieved from http://ec.europa.eu/digital-agenda/sites/digital-agenda/files/ministerial-declaration-on-egovernment-malmo.pdf

[18] European Commission. (2010). Digital Single Market. Retrieved June 4, 2014, from http://ec.europa.eu/dgs/connect/en/content/digital-single-market 
[19] European Commission. (2010b). Europe 2020: Commission proposes new economic strategy. Retrieved June 5, 2014, from http://ec.europa.eu/news/economy/100303 en.htm

[20] European Commission. (2012). Digital 'to-do' list: new digital priorities for 2013-2014. Retrieved from http://europa.eu/rapid/press-release_IP-12-1389_en.htm

[21] European Commission. (2012b). Open Internet: Regulatory Coordination \& Users (Unit B.2). Retrieved from http://ec.europa.eu/dgs/connect/en/content/open-internet

[22] European Commission. (2012C). eGovernment Benchmark Framework 2012-2015 (EC Report). SMART 2012/0034-1. Retrieved from http:/lec.europa.eu/digitalagenda/sites/digitalagenda/files/eGovernment $\% 20$ Benchmarking\%20 method\%20paper\%20published\%20version_0.pdf

[23] European Commission. (2013). Member States' competitiveness: Performance and Implementation of EU Industrial Policy. Industrial Performance Scoreboard (EC Report). Ref. Ares(2013)3770529 - 19/12/2013

[24] European Commission. (2014). Creating a Connected World: ICT must be at the centre of the development agenda [SPEECH/14/401]. Retrieved June 3, 2014, from http://europa.eu/rapid/press-release_SPEECH-14401 en.htm

[25] European Commission. (2014a). Digital Agenda for Europe. Retrieved June 4, 2014, from http://ec.europa.eu/digital-agenda/en/digital-agenda-scoreboard \&'Digital Agenda Scoreboard 2014' [Video podcast] Retrieved from http://ec.europa.eu/digital-agenda/en/news/digital-agenda-scoreboard-2014-video

[26] European Commission. (2014b). EU eGovernment Report 2014 shows that usability of online public services is improving, but not fast. Retrieved June 14, 2014 from http://ec.europa.eu/digital-agenda/en/news/euegovernment-report-2014-shows-usability-online-public-services-improving-not-fast

[27] European Commission. (2014c). Delivering on the European Advantage? eGovernment Benchmark (EC Report). Retrieved from http://www.capgemini.com/egov-benchmark

[28] European Council. (2012) EUCO 76/12 Conclusions [CO EUR 4/CONCL 2], June 28-29. Retrieved from http://www.consilium.europa.eu/uedocs/cms_data/docs/pressdata/en/ec/131388.pdf

[29] European Policy Centre. (2010). Establishing the Digital Single Market: policy recommendations. Retrieved from http://www.epc.eu/dsm/6/Policy_recommendations.pdf

[30] Eurostat. (2009). Statistics on Information Society. Retrieved from:

[31] http://epp. eurostat.ec.europa.eu/portal/page/portal/information_society

[32] Jackson, M. (2010). The Definition of UK Superfast Next Generation Broadband. Retrieved June 4, 2014, from the ISP Review: http://www.ispreview.co.uk/articles/10_Definition_of_UK_Superfast_NGA_Broadband/03.php

[33] Mettler, A. (2012a, May 23). Europe Needs a Real Growth Agenda [Web log post]. Retrieved from http://www.euractiv.com/euro-finance/europe-needs-real-growth-agenda-analysis-512917

[34] Mettler, A. (2012b, June 13). Unleash Europe's Digital Revolution to kick-start growth [Web log post]. Retrieved from http://forumblog.org/2012/06/unleash-europes-digital-revolution-to-kick-start-growth/

[35] MICUS. (2008). The Impact of Broadband on Growth and Productivity (Research Study). Retrieved from http://breitbandinitiative.de/wp/wp-content/uploads/2009/04/2008_micus-studie-broadbandeu_long.pdf

[36] Organisation for Economic Cooperation and Development. (2011). Evolving Paradigms in Economic Policy Making. Retrieved from http://www.oecd.org/eco/outlook/48010330.pdf

[37] Regulation No 1211/2009 of the European Parliament and of the Council establishing the Body of European Regulators for Electronic Communications (BEREC) and the Office [2009]. OJ L 224/50.

[38] Rial, N. (2012). Europe has the potential to leapfrog the next digital revolution [Web log post]. Retrieved from http://www.neurope.eu/article/europe-has-potential-leapfrog-next-digital-revolution

[39] Serentschy, G. (2011, June). The Role of BEREC in the development of the single market. Paper presented at the Annual Conference with topic 'The Implementation of the Telecoms Regulatory Framework in EU12: Policy, Regulatory and Market Challenges', Florence, Italy. 
[40] Stassinopoulos, Y. (2013) EUROPE 2020: A new ECIPE periodic review of the EU's growth strategy [ACIPE Research, $09 / 13$ No 1]. Athens Centre for International Political Economy.

[41] Tsatsou, P. (2011). EU Regulations of Telecommunications: The Role of subsidiarity and mediation. First Monday, 16 (1). Retrieved from http://firstmonday.org/ojs/index.php/fm/article/view/3150/2745

\section{Figures}

\section{Graph nr. 1: Market types according to restrictions}

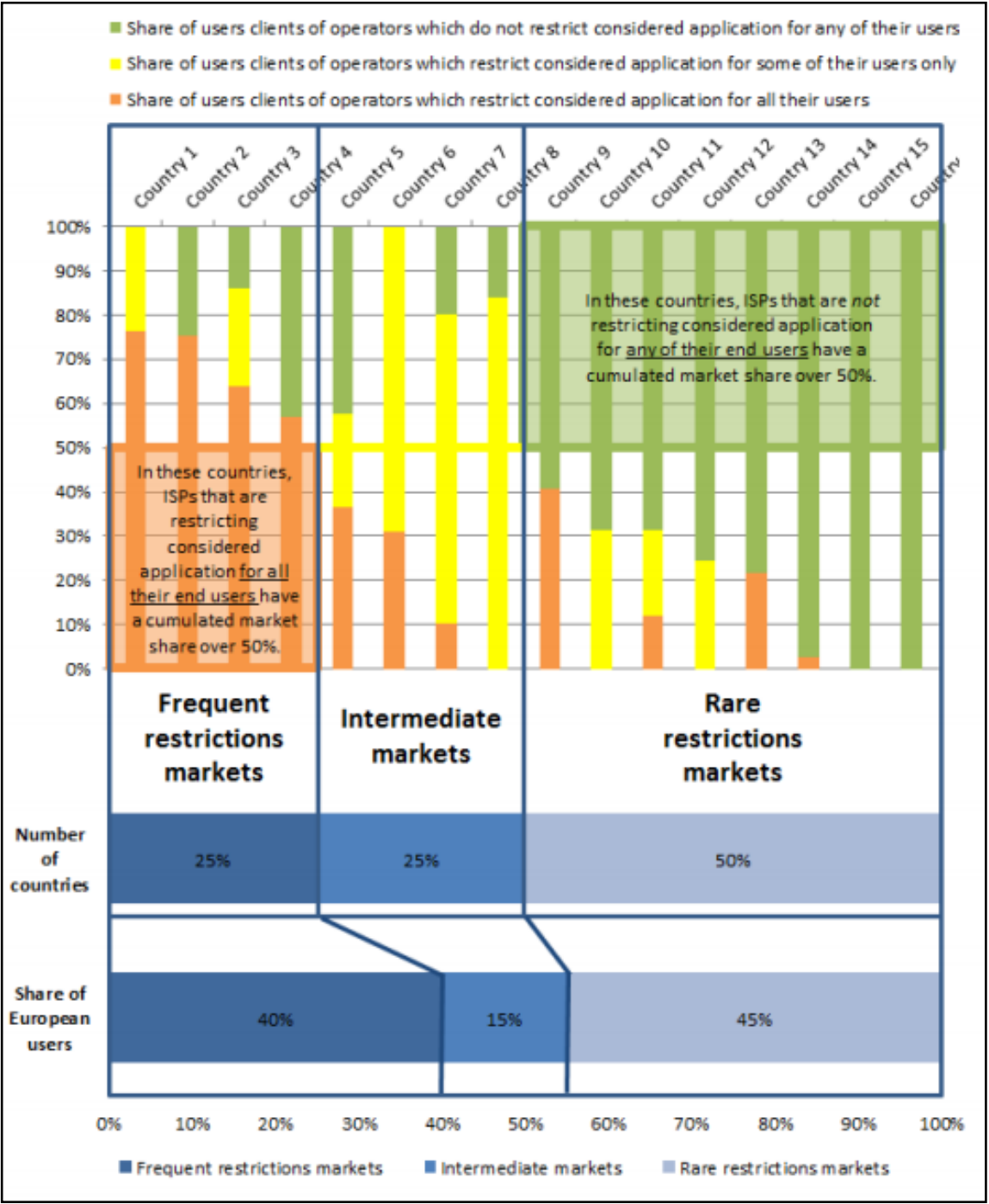

Source: BEREC, 2012, p. 25 
Graph nr. 2: Fixed Market Types - Restrictions

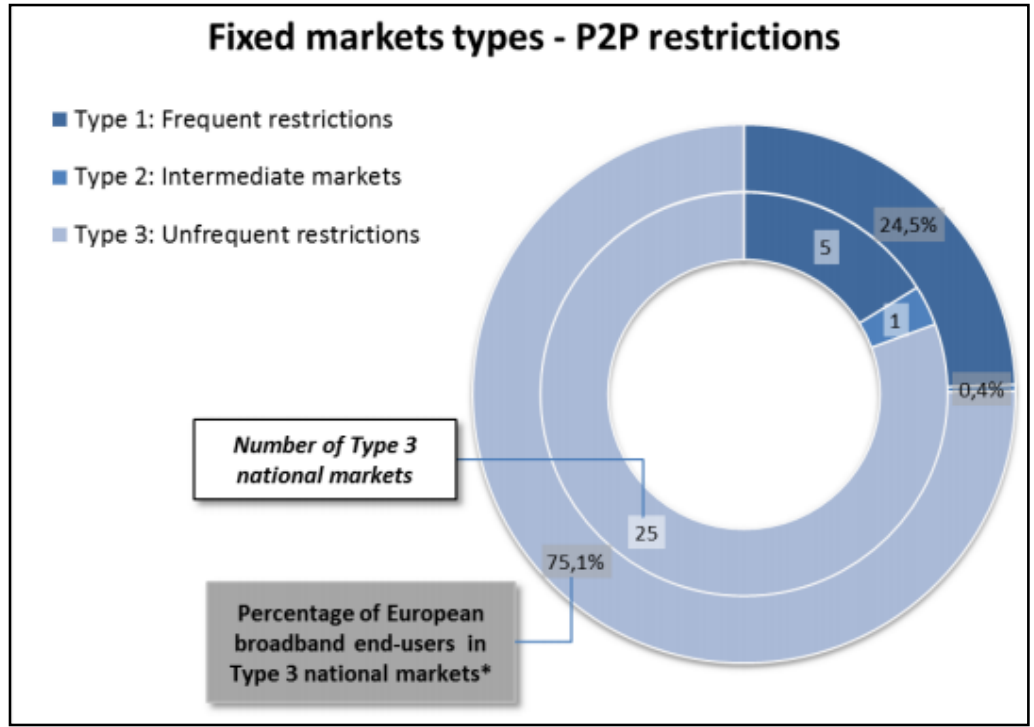

Source: BEREC, 2012, p. 26

Graph nr. 3: Mobile Market types - Restrictions

\section{Mobile markets types - P2P restrictions}

- Type 1: Frequent restrictions

= Type 2: Intermediate markets

= Type 3: Unfrequent restrictions

Number of Type 3

national markets

broadband end-users in

Type 3 national markets*

Source: BEREC, 2012, p. 27 
Graph nr. 4: Mobile Markets - Restrictions

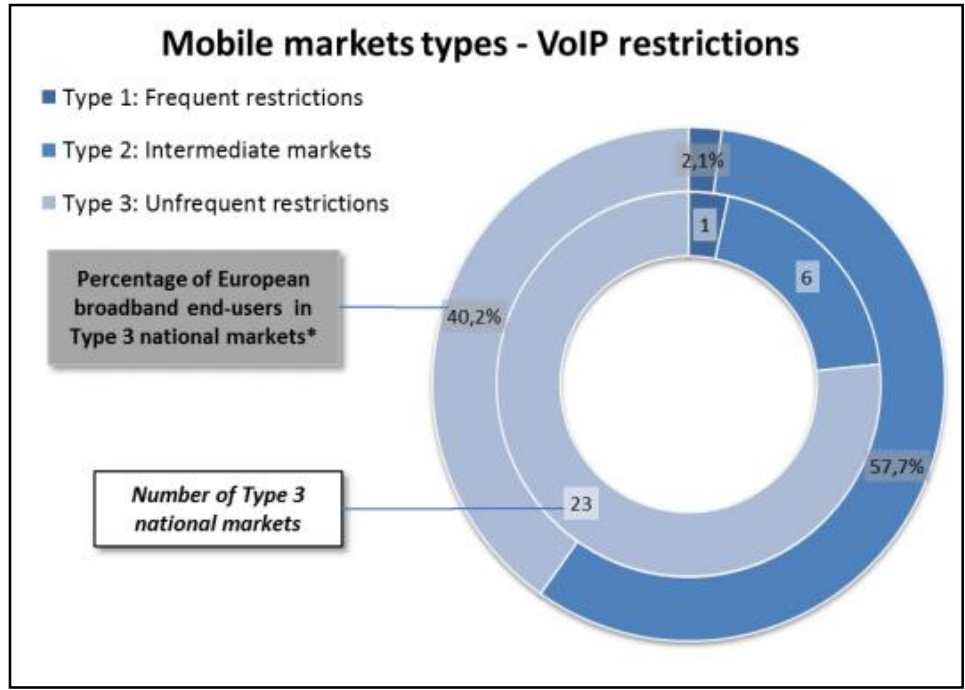

Source: BEREC, 2012, p. 28

Graph Nr. 5: Activities performed online by internet users

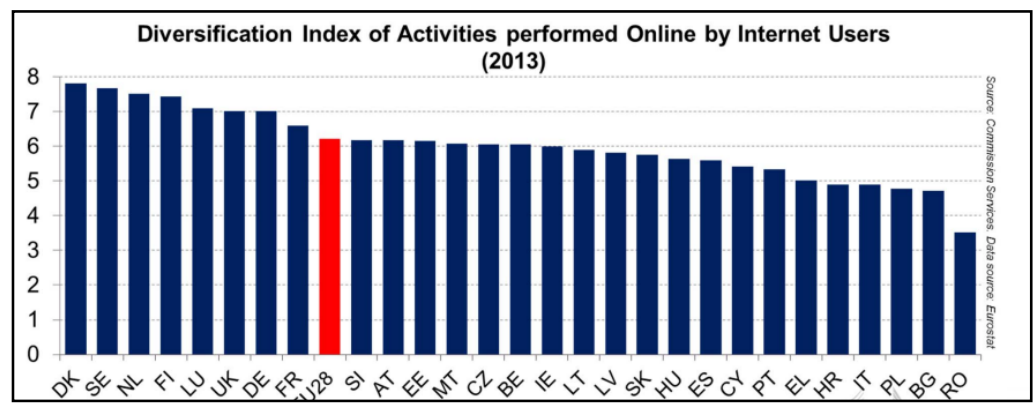

Source: European Commission, 2014a.

Graph Nr. 6: Online shopping trends by citizens

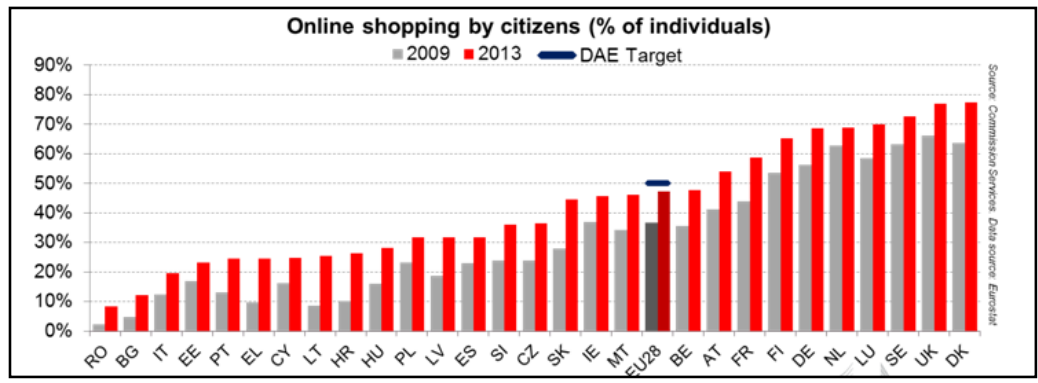


Source: European Commission, 2014a.

Graph Nr. 7, 8: Advertising Revenues, according to the type of media
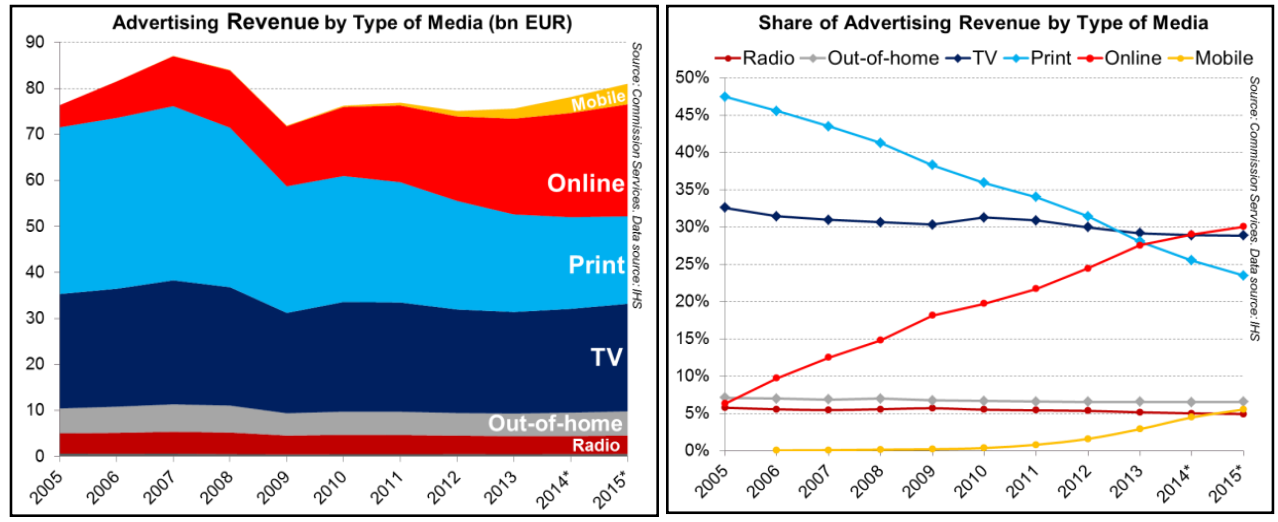

Source: European Commission, 2014a

Graph Nr. 9: Technological coverage at EU level

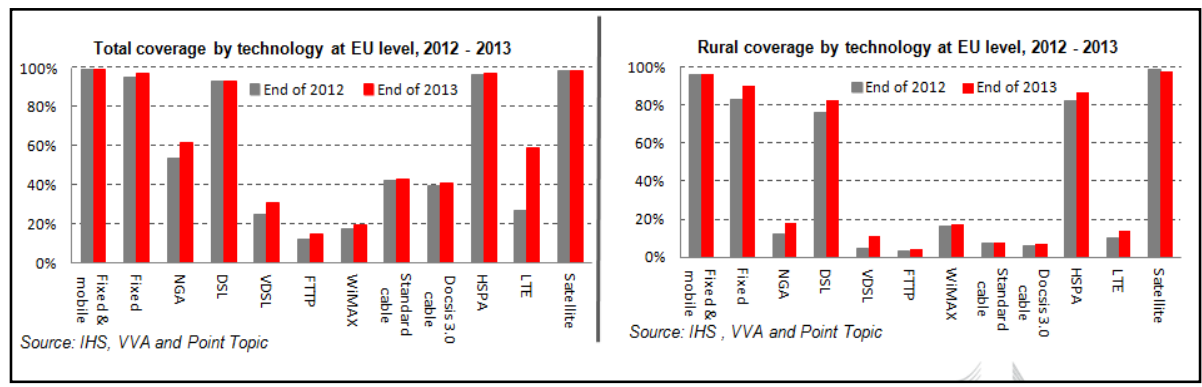

Source: European Commission, 2014a

Graph 10: Regular users of the internet in the last 3 months of 2009

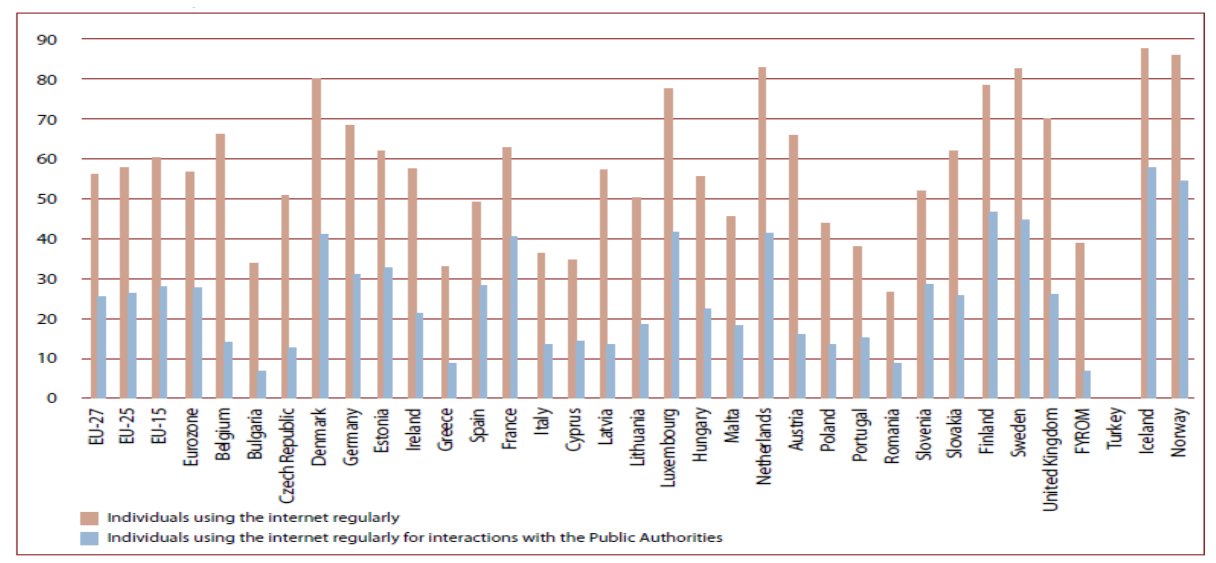




\section{Source: Eurostat, 2009}

Graph nr. 11: Key insights user survey in all EU-27 (2010-2012)

\begin{tabular}{|c|c|c|c|}
\hline eGovernment Use & $\begin{array}{l}\text { Barriers that prevent } \\
\text { eGovernment use }\end{array}$ & eGovernment Satisfaction & $\begin{array}{l}\text { Fulfillment \& Benefits of } \\
\text { eGovernment use }\end{array}$ \\
\hline $\begin{array}{l}\text { - } 46 \% \text { of users of public services } \\
\text { used eGovernment services } \\
\text { - } 54 \% \text { preferred traditional } \\
\text { channels } \\
\text { " However } 50 \% \text { of all respondents } \\
\text { indicated to prefer the } \\
\text { eChannel next time when they } \\
\text { contact government } \\
\text { - Most popular eGov service } \\
\text { (among the } 19 \text { services } \\
\text { examined): 'declaring income } \\
\text { taxes' (73\% of user will use the } \\
\text { eChannel for this service next } \\
\text { time), 'moving/chang ing } \\
\text { address within country' (57\%) } \\
\text { and 'enrolling in higher } \\
\text { education and/or applying for } \\
\text { student grant' ( } 56 \% \text { ) } \\
\text { - Least popular eGov service: } \\
\text { 'reporting a crime' (41\%), } \\
\text { 'starting a new job' (41\%) and } \\
\text { 'starting a procedure for } \\
\text { disability allowance' (42\%) }\end{array}$ & $\begin{array}{l}\text { - } 21 \% \text { was notaware of the } \\
\text { existence of relevant websites } \\
\text { or online services, mainly } \\
\text { younger people (especially } \\
\text { students), who are more } \\
\text { able/skilled and willing to use } \\
\text { eGov BUT less aware of relevant } \\
\text { services existing online } \\
\text { - } 80 \% \text { indicates a lack of } \\
\text { willingness to use eGov } \\
\text { services. This group consists of } \\
\text { relatively more women and } \\
\text { older people but also } 62 \% \text { of } \\
\text { daily Internet users } \\
\text { - } 11 \% \text { did not use Internet } \\
\text { because of concerns about } \\
\text { protection andsecurity of } \\
\text { personal data } \\
24 \% \text { was not able to use eGov } \\
\text { services. Mainly older people, } \\
\text { but also young people who } \\
\text { abandoned because the service } \\
\text { was too difficult to use }\end{array}$ & $\begin{array}{l}\text { - Satisfaction with eGovernm ent } \\
\text { services is significantly }(-2,0) \\
\text { lower than the satisfaction with } \\
\text { eBanking services (resp. } 6,5 \text { \& } \\
8,5) \\
\text { - Satisfaction with eGovernment } \\
\text { services is dropping since } 2007 \text {, } \\
\text { with } 1,3 \% \\
\text { - 'Declaring income tax' shows } \\
\text { that eGovernment services can } \\
\text { live up to citizens expectations } \\
\text { - Services around } \\
\text { (un)employment receive low } \\
\text { satisfaction scores, reflecting } \\
\text { today's economic situation }\end{array}$ & $\begin{array}{l}\text { - } 4796 \text { of eGovernment users fully } \\
\text { got what he wanted from the } \\
\text { public administration } \\
\text { - } 46 \% \text { only partially receives what } \\
\text { was looked for } \\
\text { - } 5 \% \text { did not get what he } \\
\text { wanted at all } \\
\text { - Time and flexibility gains are } \\
\text { most important to users, } \\
\text { followed by saving money and } \\
\text { simplification of a delivery } \\
\text { process. Apparently, quality of a } \\
\text { service is less relevant to } \\
\text { citizens }\end{array}$ \\
\hline
\end{tabular}

Source: European Commission, 2012

\section{Graph Nr. 12: eGovernment performance according to policy priorities}

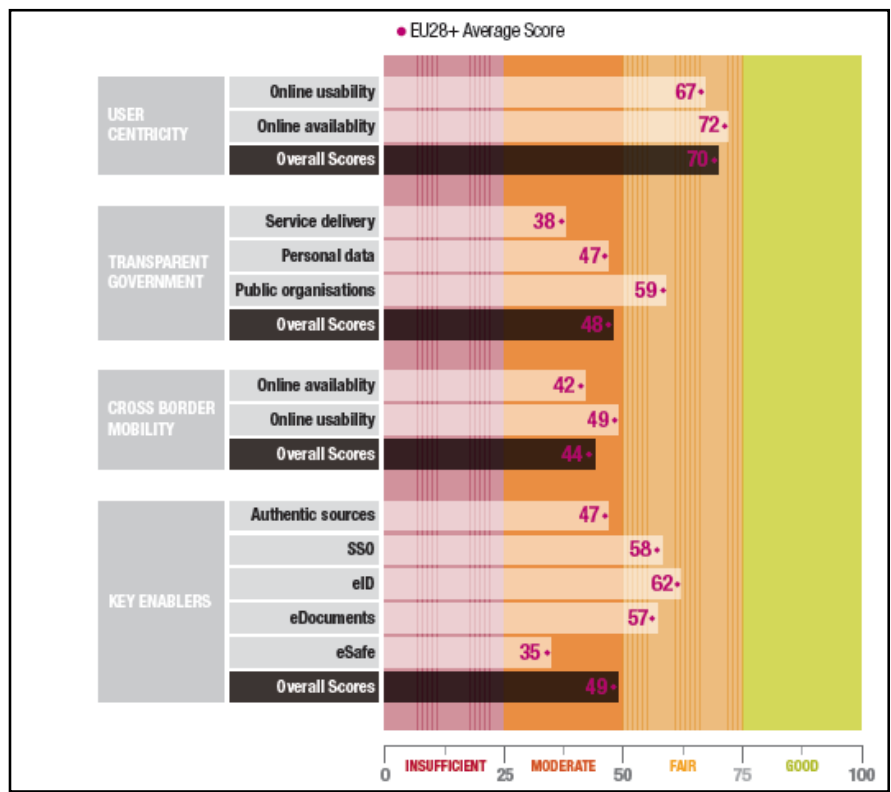


Source: European Commission, 2014c.

Graph Nr. 13: Progress report 2009-2013

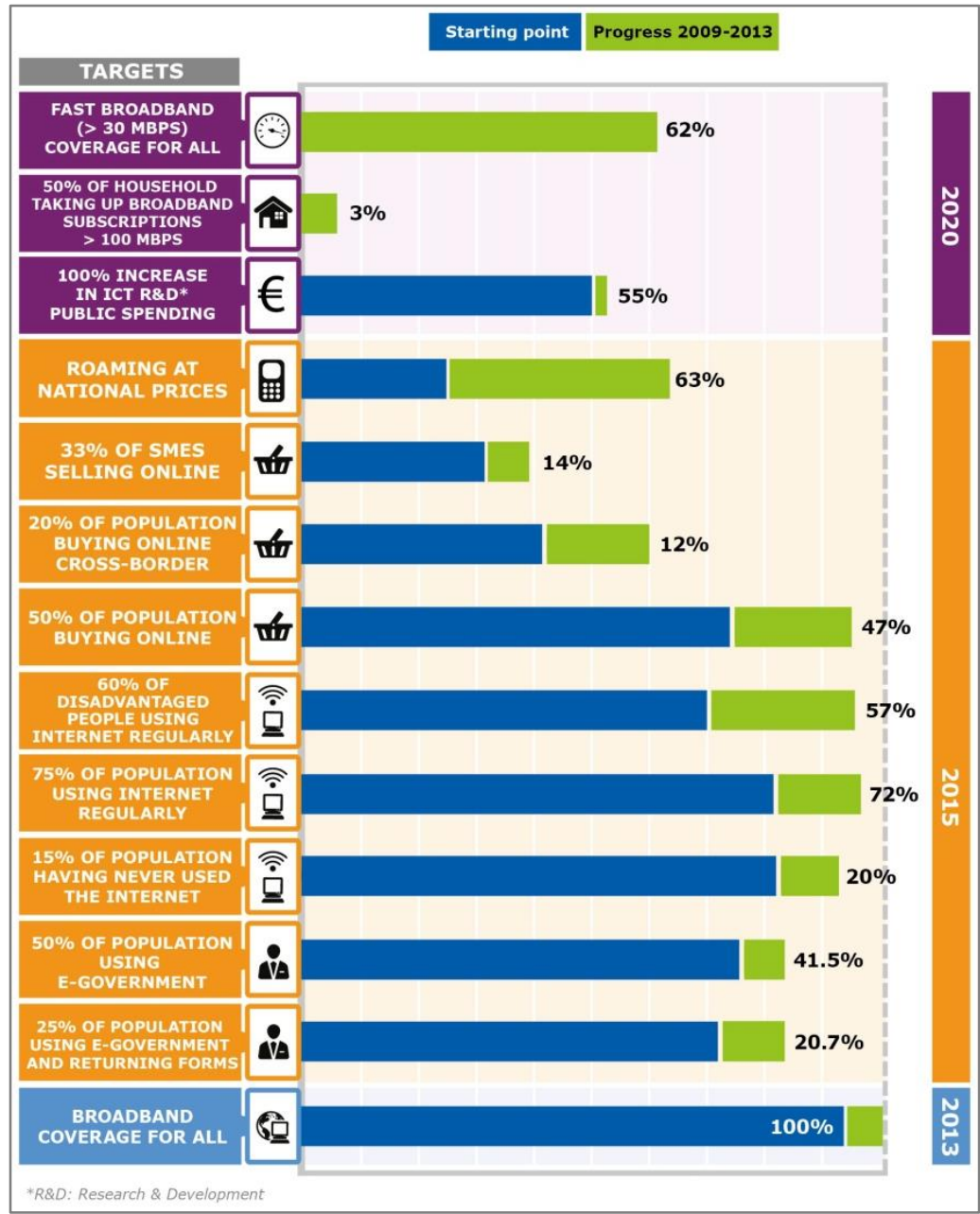

European Commission, 2014a 